\title{
WHITEHEAD VERSUS DEWEY: O FILOSOFII, RYTMU A ESTETICKÉ ZKUŠENOSTI
}

\author{
MARTIN KAPLICKÝ \\ Katedra estetiky, Filozofická fakulta, Univerzita Karlova \\ E-mail: kaplmaff@ff.cuni.cz \\ Ústav věd o umění a kultuře, Filozofická fakulta, Jihočeská univerzita v Českých Budějovicích \\ E-mail: mkaplicky@ff.jcu.cz
}

\begin{abstract}
Whitehead and Dewey on Philosophy, Rhythm and Aesthetic Experience

In their philosophical works Alfred North Whitehead and John Dewey criticize philosophical conceptions that consider the stability of the outer world to be a basic characteristic of reality and conceive of change only as its secondary feature. Both Dewey and Whitehead emphasize that different kinds of process underlie the existence of seemingly stable and unchanging objects. Consequently, both men are considered to be process philosophers. Their philosophical systems harmonize in many respects. It is surprising, then, that in their philosophical writings they rarely mention each other. This article has three main aims. Its first part is a discussion of how and where the two philosophers do in fact refer to each other, and it seeks to show how they reflect on their similarities and differences. We see their strong mutual respect but also criticism. Whitehead claims that Dewey's philosophy plays it too safe, is not metaphysically bold enough. Dewey has reservations about Whitehead's 'eternal object', which, he argues, seems to bring static idealism into Whitehead's philosophy. The second part deals with the concept of rhythm as the main ontological principle for both philosophers, and seeks to show that their treatment of this concept is strongly analogical, expressing not the repetition of the same element, but the fusion of order and novelty. The third part of the article seeks to demonstrate that for both philosophers rhythm is not only an ontological principle, but also the basic characteristic of aesthetic experience. This fact gives a strong aesthetic tinge to the philosophical systems of both Whitehead and Dewey.
\end{abstract}

Keywords: A. N. Whitehead; J. Dewey; process philosophy; rhythm; aesthetic experience

Alfred North Whitehead a John Dewey patří mezi nejvýznamněǰ̌í filosofy první poloviny 20. století a jejich úvahy silně ovlivnily další směřování filosofického myšlení. Také vývoj reflexe a vlivu jejich filosofických koncepcí je v mnohém podobný. Jak Deweyho, tak Whiteheadova filosofie byla velice vlivná mezi dvacátými a čtyřicátými lety 20. století, po nástupu a dominanci analytické filosofie však ustupují do pozadí. Vliv obou autorů nicméně znovu stoupá od let šedesátých a sedmdesátých, kdy se začínají silněji uplatňovat filosofické koncepce, které přestávají chápat analýzu výroků o světě jako hlavní klíč k uchopení skutečnosti a vracejí se $\mathrm{k}$ analýzám široce pojaté zkušenosti jako východisku filosofického zkoumání. Právě rovina zkušenosti je pro oba filosofy základní a jazyková strukturace světa musí být podle jejich názoru vždy zkoumána v souvislosti s široce pojatou zkušeností. V př́padě Whiteheada bychom mohli mluvit o obnovení zájmu o jeho 
filosofii ve filosofických dílech takových autorů, jako jsou Charles Hartshorne, Donald Sherburne, David Ray Griffin, John Cobb, Isabelle Stengers, Ilya Prigogine nebo Gilles Deleuze, v současnosti se k jeho myšlenkám vrací např́lklad Graham Harman či Steven Shaviro. Deweyho filosofie zase silně ovlivnila autory tzv. neopragmatismu, jako jsou Richard Rorty, Stanley Cavell nebo Richard Shusterman, v současné době z ní těží Alva Noë. Myšlenky obou autorů však výrazně rezonují i v úvahách současné environmentální filosofie a estetiky. Jejich vliv tedy přetrvává dodnes.

Vrátíme-li se do doby, kdy Whitehead i Dewey své filosofické systémy vytvářeli, můžeme si všimnout, že oba filosofové velice dobře znali úvahy toho druhého a značně je respektovali. Oba je možné považovat za filosofy, kteří se snažili navrhnout alternativní filosofické modely vůči systémům, které vycházely z předpokladu světa jako souboru samostatně uchopitelných entit, jež teprve následně mohou vcházet do vzájemných vztahů. Pro oba byl předpoklad takto samostatně existujících objektů jako východiska filosofického systému problematický, protože vychází z abstrahované hypotetické situace, považované za to nejkonkrétnější a nejzákladnější, od čeho se má jakýkoliv filosofický systém odrazit. Oba upozorňují na to, že jakýkoliv objekt je nám dán ve svých vztazích a existuje vždy již ve vztazích k jiným objektům svého prostředí. Tyto vyvíjející se, procesuální vztahy tedy nejsou vzhledem k objektům něčím sekundárním, ale tvoří jádro toho, jak a čím daný objekt je.

Proto mohou být oba myslitelé považováni za procesuální filosofy, pro něž dualistická rozlišení nejsou pevným východiskem jejich koncepcí, ale výsledkem procesů, které probíhají v pozadí. Zdánlivě ostré duality jako subjekt vs. objekt, příroda vs. společnost, duše vs. tělo se proto jeví jako určité dočasné konstelace skutečnosti, vycházející z ne vždy plně reflektovaných procesů. Obě filosofie rovněž sdílejí stejný směr uvažování, který vychází od analýzy žité zkušenosti směrem k relevanci různých typů dualit, a nikoliv naopak.

V tomto kontextu může poněkud překvapit, že vzájemných zmínek a citací obou autorů je relativně málo a kromě obligátního ocenění filosofie toho druhého téměř vždy skrývají určitou kritickou notu. Právě reflexe jejich vzájemných zmínek bude tématem následujícího textu, především jeho první části. Druhá část bude věnována jejich pojetí rytmu, protože problematika rytmu jakožto komplexního procesu se u obou dostává do samotného centra jejich filosofických systémů. Kromě toho, že rytmus v pojetí obou autorů nabývá podoby ontologické charakteristiky skutečnosti, spojují jej s problematikou estetické zkušenosti a umění. Souvislosti rytmu a estetické zkušenosti bude věnována třetí část tohoto textu.

\section{I.1 Whitehead o Deweym}

Začneme-li Whiteheadovými zmínkami o Deweyho filosofii, musíme se nejprve zastavit u drobné poznámky v předmluvě k jeho nejrozsáhlejší a nejznámější filosofické knize Proces a realita. Esej o kosmologii. Whitehead zde uvádí filosofy, kteří ovlivnili jeho vlastní filosofický systém, a mezi svými současníky zmiňuje Henriho Bergsona, Williama Jamese a Johna Deweyho. Př́mo zde tvrdí: „Jsem také velice zavázán Bergsonovi, Williamu Jamesovi a Johnu Deweymu. Jedním z mých cílů bylo zbavit jejich způsob 
myšlení nařčení z antiintelektualismu, které s nimi bylo, at už oprávněně nebo neoprávněně, spojováno."1

Dewey je zde zařazen mezi autory, jejichž myšlení Whiteheada silně ovlivnilo. Whitehead má však potřebu způsob myšlení těchto autorů „zbavit nařčení $\mathrm{z}$ antiintelektualismu“. Naznačuje také, že tento antiintelektualismus s jejich myšlením nemusí být vždy spojován po právu. Proč je však pro Whiteheada vyvrácení výtky antiintelektualismu tak důležité? Intelektualismus je ve filosofiích zmíněných autorů spojován především s mechanickou interpretací skutečnosti prostřednictvím dřive rozumem ustavených kategorií (subjekt vs. objekt, subjekt vs. predikát, kultura vs. příroda), které jsou bud’ příliš široké, nebo př́liš úzké, a naše původní zkušenost je tak jejich prostřednictvím zkreslována. ${ }^{2}$ Proti tomuto zkreslování přitom vystupoval i sám Whitehead, který však intelektuální nahlédnutí skutečnosti nepovažuje pouze za aplikaci zažitých myšlenkových schémat. Pokládá ho také za nezbytnou součást každého porozumění skutečnosti, které směřuje mimo již ustavené způsoby porozumění světu. Je pravda, že zažité způsoby abstrakcí nám užitečně zjednodušují skutečnost, avšak ze stejného důvodu nás mnohdy klamou. Pokud např́iklad řekneme, že nějaký člověk je dobrotivý, a nahlížíme tento výrok i danou osobu z hlediska vztahu mezi substancí a atributem, máme tendenci chápat jeho osobnost jako základní substanci a jeho dobrotivost jako jeden z jeho více nebo méně nahodilých atributů. To, že dobrotivost je neoddělitelná od dané osobnosti jako takové, že daný člověk existuje skrze svou dobrotivost a podoba jeho dobrotivosti se vyvíjí současně s jeho osobností, je v tomto abstrahovaném subjekt-predikátovém modelu přehlíženo. Tohoto nebezpečí si byl Whitehead samozřejmě vědom. Cesta k adekvátnějšímu poznání však podle něj nevede skrze zřeknutí se problematického pojmového racionálního aparátu, ale naopak skrze jeho důkladnější propracovávání a revizi. Whitehead např́iklad stejně jako Bergson kritizuje filosofický předpoklad jednoduchého umístění věcí v nezávisle existujícím prostoru a jejich zkoumání bez ohledu na jejich vývoj v rámci temporální dimenze. Tento filosofický předpoklad nazývá klamem jednoduchého umístění (fallacy of simple location). $\mathrm{V}$ této souvislosti tvrdí:

Toto jednoduché umístění okamžitých materiálních konfigurací je tím, proti čemu protestoval Bergson, vztahovalo-li se k času a bylo-li považováno za základní fakt konkrétní př́rody. Nazývá ho pokřivením (distorsion) př́rody kvůli intelektuální „spacializaci“ věcí. Souhlasím s Bergsonem $\mathrm{v}$ jeho protestu, ale nesouhlasím s tím, že takové pokřivení je nutně nešvarem intelektuálního uchopení př́rody. $V$ následujících přednáškách se budu snažit ukázat, že tato spacializace je vyjádřením konkrétnějších faktů způsobem, který skrývá velice abstraktní logické konstrukce. Jedná se o chybu, je to však pouze nahodilá chyba záměny abstraktního za konkrétní. Je př́kladem toho, co budu nazývat „klamem chybně situované konkrétnosti“. Tento klam je zdrojem velkých zmatků ve filosofii. Intelekt však nemusí nutně do této pasti upadnout, i když v tomto př́ípadě se tak všeobecně dělo. ${ }^{3}$

1 A. N. Whitehead, Process and Reality: An Essay in Cosmology, Corrected Edition, The Free Press, New York 1978, s. xii.

2 Srov. H. Bergson, Myšlení a pohyb, Mladá fronta, Praha 2003, s. 32-34; W. James, Pragmatismus: Nové jméno pro staré zpi̊soby myšlení, Centrum pro studium demokracie a kultury, Brno 2003, s. 51-53; J. Dewey, Experience and Nature, George Allen \& Unwin, London 1929, s. 16.

3 A. N. Whitehead, Science and the Modern World, Macmillan, New York 1964, s. 74-75. 
Na této pasáži můžeme sledovat, že podle Whiteheada není za zkreslování filosofického náhledu na skutečnost zodpovědný intelekt, ale spíše jeho chybné použití. Whitehead užívá pojem intelekt v širším významu než Bergson a dá se říci, že rozpětí tohoto pojmu se v jeho pojetí překrývá s pojmem racionalita. Tento pojem však v sobě ve významu, který mu Whitehead uděluje, obsahuje nejen aplikaci již ustavených kategorií na analýzu skutečnosti, ale vlastní produktivní sílu, jejímž prostřednictvím tyto kategorie ustavujeme. Klam chybně umístěné konkrétnosti, o kterém v citátu hovoří, je podle jeho názoru jednou z častých chyb filosofických zkoumání, ale i každodenního nahlížení skutečnosti. Spočívá v tom, že za plně konkrétní jev pokládáme naše nepřiznané zjednodušení skutečnosti, a tím realitu zkreslujeme. Mohli bychom říci, že Bergson, James i Dewey se ve svých zkoumáních pokoušeli atakovat různé typy klamů chybně umístěné konkrétnosti a nalézat $\mathrm{k}$ nim alternativní způsoby vysvětlení. Právě tento moment v jejich myšlení Whitehead oceňuje. Současně však u nich nachází určité podcenění či nedůvěru k intelektu a racionalitě, s níž se nemůže ztotožnit.

Nejúčinnějším bojem proti různým podobám klamu chybně umístěné konkrétnosti není podle Whiteheada jeho prosté odmítnutí a navržení alternativy. Je jím podle něj vytvoření tak obecného a jemného filosofického systému, aby dokázal problematický předpoklad zahrnout do svého jazyka a umístit ho do toho patra obecnosti, do něhož v jeho rámci prrísluší. Vytvoření ideálního filosofického systému je sice podle Whiteheada nemožné, neměli bychom však rezignovat na pokus se k němu přiblížit, protože jen díky němu můžeme nahlédnout vztahy různých podob skutečnosti v co nejširších relacích. Pokud se ukáže, že daný filosofický systém v některých rysech neodpovídá skutečnosti, je třeba vyvinout systém jiný, který dokáže osvětlit nejen chybějící rysy systému předchozího, ale i důvody tohoto přehlédnutí.

Svět v jeho plné konkrétnost leží mimo dosah naší zkušenosti. Naše zkušenost je vždy určitým výběrem z masy možností, které realita nabízí. Filosofie by se však podle Whiteheadova názoru měla snažit proniknout co nejblíže ke konkrétnímu a může toho dosáhnout jen tím, že bude produkovat co nejjemnější kategoriální schémata, která nahradí a osvětlí dosavadní způsoby chápání reality. Racionalita a intelektuální vhled pro něj tedy neznamenají jen aplikování předem přijatých myšlenkových kategorií na zkušenost, ale především rozvíjení co nejúplnějšího pojmového schématu, které nám umožní nahlédnout na zkušenost způsobem přesahujícím naše již ustavené způsoby porozumění. To by měl být, podle jeho názoru, také hlavní cíl filosofických, metafyzických systémů. ${ }^{4}$ Sám v tomto ohledu zdůrazňuje, že „[m]etafyzické kategorie nejsou dogmatickými vyjádřeními zřejmého, ale zkusmými formulacemi nejvyšší obecnosti“. ${ }^{5}$

Filosofické úvahy by se tedy neměly zříkat cíle vyjádřit co nejobecnější principy skutečnosti a současně by měly co nejintenzivněji komunikovat s naší konkrétní zkušeností. Ta je však často formována nepřiznanými abstrakcemi, které pokládáme za samozřejmé a plně konkrétní. Při rozvíjení co nejadekvátnějšího filosofického systému proto není podle Whiteheada možné jednoduše vyjít ze samozřejmých obecných principů a na jejich základě budovat bezespornou teorii. K těmto obecným principům se máme filosofickou

4 Metafyziku Whitehead chápe jako filosofický projekt, který se snaží uchopit realitu v její plné komplexitě. Je to filosofický systém, který nepohodlnou otázku nemůže odbýt výrokem: „To se mého způsobu uvažování již netýká. “ Metafyziky se ve Whiteheadově smyslu týká vše.

5 Whitehead, A. N., Process and Reality: An Essay in Cosmology, viz výše, s. 8. 
úvahou teprve přiblížit. Není však možné ani jednoduše začít popisovat naši př́ímou konkrétní zkušenost, protože ta nikdy není zcela přímá. Je zprostředkovaná našimi navyklými způsoby konceptualizace.

Filosofie by podle Whiteheada měla na základě popisu určité zkušenosti generalizovat obecné principy, které tuto zkušenost překračují, imaginativně je rozvinout a takto získané obecné principy následně opět podrobit zkoušce aplikovatelnosti na co nejširší zkušenostní pole. To povede k poupravení pojmového schématu, ale současně i k novým možnostem náhledu na skutečnost. Tuto metodu konstrukce pojmového filosofického schématu Whitehead nazývá metodou deskriptivní generalizace.

Cesta $\mathrm{k}$ plně adekvátnímu pojmovému schématu není podle Whiteheada nikdy zcela završitelná, přesto by filosofické úvahy podle jeho názoru neměly rezignovat na cíl formulovat co nejadekvátnější obecné pojmové schéma. A nezbytnou součástí tohoto cíle ji i racionalizace (intelektualizace) zkušenosti. V pozoruhodné pasáži Whitehead tvrdí:

Poté, co byly ustaveny počáteční základy racionálního života s jeho civilizovaným jazykem, postupovalo veškeré produktivní myšlení bud’ skrze poetický vhled umělců, nebo skrze imaginativní rozvinutí myšlenkových schémat, která bylo možné využít jako logické premisy. Vývoj je vždy do určité míry překračováním toho, co je zřejmé. Racionalismus nikdy nemůže setřást svůj status experimentálního dobrodružství. Společný vliv matematiky a náboženství, který tak výrazně přispěl ke vzniku filosofie, na ni měl také nepříznivý vliv v tom, že ji svázal statickým dogmatismem. Racionalismus je dobrodružství při objasňování myšlení, dobrodružství, které se vyvíjí a nikdy není uzavřeno. V tomto dobrodružství má však význam i dílčí úspěch. ${ }^{6}$

Citát ukazuje, že Whitehead za jádro racionality, a tedy i intelektuálního vhledu nepovažuje bezesporné vyvozování závěrů z předem přijatých axiomů pokládaných za zřejmé, ale vyjasňování našich zažitých myšlenkových postupů, směřující k objevení nových skutečností. V tomto smyslu je tedy racionalismus „překračováním zřejmého“. Když Whitehead mluví o dobrodružném charakteru racionalismu, má dle mého názoru na mysli to, že budování nového pojmového schématu má vždy hypotetickou povahu, vždy obsahuje možnost, že nebude zcela adekvátní.

V citátu se navíc objevuje i zajímavá paralela mezi poetickým vhledem umělců a budováním racionálního pojmového schématu. Obě tyto aktivity mají společné to, že posouvají naše poznání skutečnosti mimo to, co již víme. S tím souvisí i jejich práce s jazykem. Jak umění, tak filosofie překračují ustavené významy slov, budují nový typ slovníku, který dokáže popsat rysy reality schované za tím, co se nám jeví jako zřejmé. Filosofické úvahy by podle Whiteheada měly směřovat $\mathrm{k}$ co neúplnějšímu pojmovému schématu, protože jen tehdy budou moci vysvětlit vztah toho, co bylo nezjevné, k tomu, co se dříve jevilo jako zcela samozřejmé. Racionalita a intelektuální vhled v takto vymezeném smyslu mají ve Whiteheadově pojetí filosofie zcela klíčovou roli, a proto se vymezuje proti náhledům, které roli takto definované racionality a intelektu, a tedy i cíle filosofických zkoumání omezují. U každého z výše zmiňovaných autorů by toto omezení mělo jiný charakter, a bylo by ho tedy tř̌eba pečlivě rozvést. Soustřed’me se však nyní na Whiteheadův vztah $\mathrm{k}$ Deweyho filosofii.

6 Tamtéž, s. 9. 
S Deweyho kritikou intelektualismu ve smyslu filosofie, která veškerou zkušenost odvozuje od zkušenosti kognitivní a vlastní pojetí zkušenosti tím nepřiměřeně omezuje, by Whitehead jistě souhlasil. Sám totiž - aniž by používal pojem intelektualismus - formuluje podobný názor. Vztah poznávajícího a poznávaného očištěný od všech ostatních složek zkušenosti je podle Whiteheada vysokou abstrakcí. Odvozování veškeré zkušenosti z takto abstrahované kognitivní zkušenosti by tedy spadalo do klamu chybně situované konkrétnosti, nebylo by spolehlivé a vyžadovalo by revizi. ${ }^{7}$ Dewey navíc zdůrazňuje, že kritikou intelektualismu ani v nejmenším nechce snižovat roli rozumu a intelektu. ${ }^{8}$ $\mathrm{V}$ tomto ohledu by tedy Whitehead zřejmě nic nenamítal.

V krátkém textu „John Dewey a jeho vliv“ Whitehead velmi oceňuje Deweyho schopnost odhalovat nezjevné skutečnosti, kterou sám od filosofického zkoumání vyžaduje, a kromě toho u Deweyho filosofie vyzdvihuje její silný a plodný vliv na společnost. ${ }^{9}$ Tvrdí dokonce, že „žijeme uprostřed období Deweyho vlivu“. ${ }^{10}$ Celý tento drobný text lze vnímat jako projev uznání velkému současníkovi. Přesto i zde můžeme nalézt určitou stopu kritického ostnu. V momentu, kdy oceňuje silný společenský a reformátorský vliv Deweyho filosofie, totiž Whitehead také poznamenává, že „znamenitost Deweyho díla ve vyjádření pojmů, které jsou relevantní pro moderní civilizaci, zvyšuje nebezpečí sterilizace myšlení v hranicích dneška". ${ }^{11}$ Deweyho oceňovaný důraz na to, že filosofie má být v co nejtěsnějším kontaktu s žitou skutečností své doby, aby se neutopila v planých abstrakcích a verbalismech, může být podle Whiteheada i nebezpečný. Může totiž svádět $\mathrm{k}$ tomu, abychom smysl filosofie hledali jen $\mathrm{v}$ tom, jak může přispět $\mathrm{k}$ orientaci v aktuálních problémech naší doby. Otázky přesahující problémy současnosti by se tak mohly jevit marné a zbytečné. Toto omezení pozornosti jen na zkušenosti, které jsou při ruce, by v důsledku směřovalo k omezování dobrodružnosti myšlení (tedy podstaty racionality, tak jak ji Whitehead definuje) a rezignaci na usilování filosofie o co nejobecnější kategoriální schéma. Podle Whiteheada by tedy hlavním problémem Deweyho myšlení z hlediska problematiky racionality a intelektu byl, možná trochu překvapivě, nedostatek dobrodružnosti. Tento závěr potvrzuje i pasáž z Whiteheadových rozhovorů s Lucienem Pricem.

V kontextu rozhovoru z 27. července 1943, který se týká nezbytnosti dobrodružnosti pro produktivní způsoby myšlení a jednání, Whitehead v jednu chvíli stočí rozhovor k Deweymu a poznamenává: „Možná jste přemýšlel o mé zdrženlivosti k myšlení Johna Deweyho, to se ovšem netýká Deweyho osobně, kterého respektuji jako muže a některé aspekty jeho díla obdivuji. Tímto důvodem je důraz jeho myšlení na bezpečí (security). " ${ }^{2}$ Důrazem na bezpečí Whitehead patrně míní Deweyho nedůvěru ve filosofické systémy nejvyšší obecnosti. Whiteheadovi zde chybí odvážnější rozvinutí analýz vycházejících z aktuální zkušenosti za její hranice a pokus systematicky vybudovat co nejúplnější filosofický systém. Kvůli tomu však Deweyho filosofie z Whiteheadova hlediska nezohledňuje

\footnotetext{
Srov. A. N. Whitehead, Adventures of Ideas, Free Press, New York 1967, s. 175-176.

8 Srov. J. Dewey, Experience and Nature, viz výše, s. 21.

9 A. N. Whitehead, John Dewey and His Influence, in: P. A. Schilpp (ed.), The Philosophy of John Dewey, Northwestern University, Evanston \& Chicago 1939, s. 478.

10 Tamtéž, s. 477.

11 Tamtéž, s. 478.

12 A. N. Whitehead, Dialogues, Little, Brown and Company, Boston 1954, s. 255.
} 
řadů souvislostí, a je-li chápána jako metafyzický systém, pokřivuje obraz skutečnosti tím, že ho redukuje jen na určitý aktuální výsek reality. Pokud se ovšem na Whiteheadovu filosofii podíváme optikou Johna Deweyho, bude výsledný obraz výrazně jiný.

\subsection{Dewey o Whiteheadovi}

Jestliže Alfred North Whitehead přímo odkazuje k Johnu Deweymu jen několikrát, ani John Dewey neodkazuje k Whiteheadovi často. Nejsoustředěnější pozornost jeho myšlení věnuje v článku „Whiteheadova filosofie“, který vzešel z příspěvku, jejž Dewey přednesl 29. prosince 1936 na sympoziu věnovanému Whiteheadově filosofii. ${ }^{13}$ Dewey zde výrazně oceňuje Whiteheadův klíčový pojem aktuální událost (actual occasion) a jeho široké použití pojmu zkušenost. Zdůrazňuje, že Whiteheadovo pojetí aktuální události a zkušenosti se netýká pouze zkušenosti lidské, ale i způsobu, jakým existují neživé skutečnosti. Díky tomu může Whitehead ukázat kontinuitu a analogičnost mezi výsledky přírodních věd a charakterem lidské zkušenosti. Právě díky této kontinuitě a analogičnosti Whitehead podle Deweyho úspěšně objasňuje př́mou lidskou zkušenost skrze výsledky př́rodních věd a tyto výsledky naopak obohacuje vztahem k lidské zkušenosti. Dewey o Whiteheadovi tvrdí:

Nedokážu si představit, jak by někdo, kdo není podrobně obeznámen s teorií fyzikálních polí a kdo současně nemá odvahu tyto teorie imaginativně vztahovat na deskriptivní generalizaci lidské zkušenosti, mohl dojít $\mathrm{k}$ tolika závěrům o lidské zkušenosti, kterých dosáhl Whitehead. Za mimořádný příklad považuji klam jednoduchého umístění (fallacy of simple location). ${ }^{14}$

Na tomto citátu můžeme sledovat, že Dewey oceňuje Whiteheadovu schopnost propojovat úvahy o lidské zkušenosti s detailními popisy př́rodních věd. K tomuto propojení kromě Whiteheadovy detailní obeznámenosti s výsledky moderní matematiky, logiky a fyziky přispěla podle Deweyho i jeho metoda deskriptivní generalizace. Tato metoda, jak jsme viděli výše, Whiteheadovi umožňuje vzájemné obohacování přímé zkušenosti a konceptuálního schématu, které bylo na jejím základě imaginativně rozvinuto. Výše jsme také viděli, že Whitehead tuto filosofickou metodu považuje za projev racionalismu. To však Deweymu nebrání pokládat ji za metodu vesměs empirickou, a tedy z jeho hlediska opodstatněnou. Tvrdí dokonce, že „[d]eskriptivní generalizace zkušenosti je cílem jakéhokoliv rozumného empirismu“. ${ }^{15}$ Zůstává však velice nedůvěřivý vůči Whiteheado-

13 Srov. J. Dewey, Whitehead's Philosophy, The Philosophical Review, roč. 46, 1937, č. 2, s. 170-177. Pro nás je v tomto ohledu zajímavé, že kromě Deweyho se tohoto sympozia účastnil i Andrew Ushenko a Gregory Vlastos a Whitehead, který byl na konferenci přítomen, na všechny př́spěvky odpověděl textem, který pod jménem „Poznámky“ vyšel také v časopise Philosophical Review a později byl pod názvem „Analýza významu“v téměř nezměněné podobě zařazen do souboru studií Eseje o vědě a filosofii. Srov. A. N. Whitehead, Remarks, The Philosophical Review, roč. 46, 1937, č. 2, s. 178-186, a A. N. Whitehead, Analysis of Meaning, in: A. N. Whitehead, Essays in Science and Philosophy, Rider and Company, London 1948, s. 83-99.

14 J. Dewey, Whitehead's Philosophy, viz výše, s. 173.

15 Tamtéž, s. 170. 
vu požadavku, aby filosofický systém konstruoval co nejúplnější pojmové schéma, jehož prostřednictvím je možné interpretovat zkušenost. Obzvláště problematická je podle jeho názoru Whiteheadova definice spekulativní filosofie jako „úsilí o sestrojení koherentního, logického, nutného systému obecných idejí, pomocí něhož může být interpretován každý prvek naší zkušenosti“. ${ }^{16}$ Definovaný cíl filosofie jako „koherentního, logického a nutného filosofického systému“ a Whiteheadovo podrobné definování jeho základních pojmů, které v Procesu a realitě předchází úvahám o jejich oprávněnosti a podobá se matematickým axiomům, vzbuzuje podle Deweyho podezření, že Whiteheadův systém obsahuje stopy tradičního a priori konstruovaného racionalismu. Dewey se snaží ukázat, že v rámci Whiteheadova systému můžeme nalézt dvě interpretační strategie, matematicko-formální model výkladu a geneticko-funkční model výkladu.

Matematicko-formální model výkladu vychází v Deweyho interpretaci z předpokladu, že celé univerzum vykazuje určitou pevnou strukturu, kterou je třeba na základě naší bezprostřední zkušenosti odhalit a formulovat ji ve formě „přesného (succinct) systému nezávislých definic a postulátů“, které jsou následně „deduktivně propojeny“. ${ }^{17}$ Dějinný vývoj skutečnosti by byl na základě této interpretační strategie podřízen původní struktuře skutečnosti, kterou se filosofický systém snaží formulovat. Geneticko-funkční model výkladu žádnou takovou původní strukturu nepředpokládá a filosofické pojmy chápe jako pojmové nástroje, které původně vznikly na základě rozlišení, jež nám poskytuje bezprostřední zkušenost. Tyto pojmy však nevyjadřují formálně logickou strukturu skutečnosti, ale slouží k jejímu „ovlivňování (control) a organizaci (ordering)“.18 Tento přístup tedy zdůrazňuje dějinný, procesuální charakter skutečnosti, který nikdy není podřízen žádné finální pojmové struktuře. Zatímco matematicko-formální model výkladu směřuje vposled k popisu světa jako morfologické a statické struktury, geneticko-funkční model výkladu zdůrazňuje dějinný, procesuální charakter skutečnosti.

Dewey si je vědom toho, že oba modely výkladu mohou vzájemně kooperovat, přesto se však domnívá, že jeden z nich musí být vždy principem vůdčím. Ve Whiteheadově filosofii jsou podle jeho názoru rozpoznatelné obě interpretační strategie, domnívá se ovšem, že není zcela jasné, která z nich je dominujícím principem. Dewey zjevně upřednostňuje geneticko-funkční model výkladu, protože respektuje skutečnost v její procesuální povaze, zatímco matematicko-formální model podle jeho názoru směřuje k odhalení základní statické struktury, skrze niž je nahlížena a popisována naše zkušenost. Tvrdí proto, že v rámci této interpretační strategie „nemusí logicky postupovat pouze filosof“, ale „schéma př́rody a bezprostřední zkušenosti je také logickým systémem“. ${ }^{19}$ To by ale znamenalo, že by tento způsob výkladu nutně opomíjel nově se objevivší prvky skutečnosti a ve výsledku by skutečnost zkresloval.

Whiteheadovu nejednoznačnou pozici, pokud jde o dominantní metodu jeho filosofie, Dewey ilustruje na začlenění pojmu „věčný objekt“"v jeho systému. Věčné objekty jsou ve Whiteheadově systému sebe-identické formy, obecné charakteristiky skutečnosti, které přispívají k formování procesuálně pojatých aktuálních událostí do určitého finálního tvaru. Tyto aktuální události jsou jednou ze základních kategorií Whiteheadova systé-

16 A. N. Whitehead, Process and Reality, viz výše, s. 3.

17 J. Dewey, Whitehead's Philosophy, viz výše, s. 174.

18 Tamtéž, s. 175.

19 Tamtéž, s. 174. 
mu. Dewey si všímá, že Whitehead o začleňování věčných objektů do aktuálních událostí často mluví jako o „vstupu“ (ingression). Tato formulace by naznačovala, že věčné objekty mají svůj vlastní způsob existence, nezávislý na aktuálních událostech, a z této pozice do nich teprve následně mohou vstupovat. To by podporovalo tezi, že vůdčím interpretačním principem je u Whiteheada matematicko-formální model, který předpokládá předem existující formální strukturu skutečnosti, čekající na své objevení. V této souvislosti je třeba zdůraznit, že sám Whitehead nezávislou existenci věčných objektů popírá. ${ }^{20}$ I Dewey ostatně uvádí možnost jiné, geneticko-funkční intepretace vztahu věčných objektů a aktuálních událostí, kterou Whiteheadova filosofie nabízí. V rámci této intepretace by byl pojem „vstupu“ věčných objektů do aktuálních událostí jen neštastně zvoleným termínem, ve skutečnosti by se jednalo o „vynoření se“ (egression) věčných objektů z aktuálních událostí. Dewey v této souvislosti přímo píše:

Z geneticko-funkčního hlediska se takové objekty (které jsou „věčné“ v tom smyslu, že nemají prostorovo-časovou existenci) vynořují kvůli existenci problematické situace. Vynořují se původně jako hypotézy (suggestions). Následně jsou funkčním způsobem použity na aktuální skutečnost. Pokud uspějí ve vyřešení problematické situace (tím, že uspořádají jinak konfliktní prvky), ztrácejí část nebo většinu své hypotetické kvality a stávají se rutinními metodami chování. ${ }^{21}$

Na této citaci je zajímavé především to, že uvedený geneticko-funkční popis plně odpovídá Deweyho vlastnímu filosofickému systému, v jehož jádru spočívá pojetí zkušenosti jako procesu řešení „problematické situace“, do níž se dostává organismus ve vztahu ke svému prostředí. Obecné pojmy pak pro Deweyho nejsou charakteristiky skutečnosti jako takové, ale ustálené způsoby našeho vztahování se ke světu. Vidíme zde také, že vztah obecných pojmů a zkušenosti se u Deweyho týká především vztahu živých organismů $\mathrm{k}$ jejich prostředí, které mohou vyvíjet hypotézy řešící problematické situace a tyto hypotézy následně zařadit do svého rutinního chování. Pro Whiteheada by však byl tento typ vztahu věčných objektů k aktuálním událostem pouze jedním $\mathrm{z}$ možných, týkal by se organismů s rozvinutým vědomím (sám nazývá tento typ vztahu věčných

${ }^{20}$ V rámci Whiteheadových filosofických úvah můžeme rozlišit dva úzce související projekty, jeho filosofii př́rody a jeho metafyziku. Pojem „věčného objektu“ se objevuje pouze v metafyzických úvahách a znamená zde „čistou potencialitu“, neměnící se formu. Potencialita je však vždy potencialita pro to, co je aktuální, tedy pro aktuální událost (actual occasion). Věčný objekt bez toho, aby byl zakomponován do aktuální události prožitku, je ve Whiteheadově metafyzice nemožný. Věčné objekty tedy podle Whiteheada nemají zvláštní typ samostatné existence, existují vždy již uvnitř nějaké aktuální události. „Vstup“věčných objektů do nové události ve Whiteheadově systému probíhá vždy skrze prehenzi, uchopení jiných aktuálních událostí. Otázka, co bylo dřív (věčné objekty, nebo aktuální události), nedává ve Whiteheadově metafyzickém systému smysl. Aktuální událost je základní procesuální jednotka jeho filosofie, její proces však není možné popsat bez př́tomnosti věčných objektů. $V$ rámci své filosofie přírody Whitehead, jak uvidíme dále, používá pojem „objekt" pro charakterizování neměnících se rysů proměnlivých událostí. Stůl, na němž píši tento text, by byl podle Whiteheada komplexem událostí, který neustále podléhá změně. Událost mého včerejš́ího stolu by byla odlišná od události stolu dnešního. Oba tyto komplexní soubory událostí by však vykazovaly totožný, neměnný objekt - „můj stůl“. Objekt je zde tedy uchopen jako sebe-identická charakteristika proměňujících se událostí. Ani v jeho filosofii př́rody proto nemůžeme mluvit o samostatné existenci objektů. Ačkoliv se pojmy „věčný objekt" a „objekt" $v$ řadě ohledů překrývají, vykazují i určité rozdíly vznikající z odlišné povahy obou zastř̌šujících filosofických systému. Podrobný rozbor shod a diferencí obou pojmů však překračuje záměr této práce.

21 Tamtéž, s. 176. 
objektů a aktuálních událostí „návrhem“ [proposition]). V jeho vlastním systému se však vztah věčných objektů a aktuálních událostí týká i takových entit, jako jsou neživé předměty nebo elektrony, které se do problematických situací v Deweyho smyslu nedostávají. Whiteheadův filosofický postoj tedy nevystihuje ani čistě matematicko-formální způsob výkladu, který by kladl nezávislou existenci věčných objektů, ani Deweym navrhovaný geneticko-funkční model. Proto v následné reakci Deweymu zdvořile odpovídá, že nemůže přijmout jeho návrh, aby jeden z uvedených interpretačních principů považoval za vưdčí. Sám přímo tvrdí:

John Dewey mě žádá, abych si vybral mezi „geneticko-funkční“ a „matematicko-formální“ interpretací prvních principů. Od nikoho by se člověk nechtěl odchýlit méně než od Deweyho. William James a John Dewey budou vždy vynikat tím, že filosofii naplnili novým životem a novou relevancí pro moderní svět. Musím však toto rozhodnutí odmítnout. Krása filosofie spočívá v její mnohovrstevnatosti. Naším současným problémem je prolnutí (fusion) obou interpretací. Dějinný proces světa, který vyžaduje geneticko-funkční interpretaci, také vyžaduje, má-li být pochopen, nahlédnutí mezních principů existence, které vyjadřují nutná propojení v rámci tohoto toku. ${ }^{22}$

Oba filosofové tedy oceňují způsob myšlení toho druhého a jeho významný přínos pro hlubší pochopení skutečnosti. Oba však také vyjadřují podezření, že filosofie toho druhého je náchylná ke zkreslování skutečnosti. Deweyho systém je podle Whiteheada přiliš úzký, příliš zaměřený na problémy současné doby, aby dokázal pojmout skutečnost v co největší komplexitě. Tím však podle jeho názoru svádí k přesvědčení, že naše problémy jsou univerzálními problémy a že aspekty skutečnosti, které se netýkají naší přímé bezprostřední zkušenosti, neexistují. V důsledku toho ovšem dochází ke zkreslování reality, která lidskou zkušenost dalekosáhle přesahuje. Deweyho kritika Whiteheadovy filosofie míŕi do stejného místa, ale opačným směrem. Whiteheadova filosofie se podle jeho názoru v určitých místech příliš odklání od naší bezprostřední zkušenosti směrem k odvážným formulacím racionálních univerzálních principů, které mají vyjadřovat základní strukturu skutečnosti. Pokud však budeme skutečnost nahlížet $\mathrm{z}$ hlediska takto formulovaných principů, budeme mít sklon přehlížet všechny aspekty skutečnosti, které se do tohoto pojmového schématu nevejdou. Tím bude ovšem docházet ke zkreslování skutečnosti. Deweyho filosofie ve Whiteheadově interpretaci i Whiteheadova filosofie v Deweyho očích jsou tedy náchylné ke zkreslování reality. Zajímavé je, že slabinou Deweyho systému, který je proslulý svými novátorskými a revolučními myšlenkami, je podle Whiteheada vposled nedostatek odvahy k obecnějším výrokům; slabinou Whiteheadovy filosofie, jež stojí v základu celého proudu procesuální filosofie, je podle Deweyho prvek statičnosti obsažený v matematicko-formálním modelu interpretace.

Oba filosofové se shodnou v řadě svých tvrzení. Pro oba je základním východiskem filosofie zkušenost, která musí být podrobena další analýze. Oba též považují ostré filosofické duality, např. subjekt vs. objekt, příroda vs. kultura, hmota vs. mysl, za sporné, podrobují je analýze a nacházejí za nimi různé druhy procesů a interakcí. Shodně též zdůrazňují, že naše popisy vztahu organismu k objektům jeho prostředí by neměly být

22 A. N. Whitehead, Remarks, viz výše, s. 179. 
modelovány pouze na základě vztahu poznávající vs. poznávané, tedy na základě kognitivní zkušenosti. Na našem porozumění světu se silně podílí i emocionální a praktické uchopení reality. Navzdory těmto shodám jsme mohli vidět, že v základní filosofické metodě se neshodnou a neshodnou se ani v tom, v čem shledávají hrozbu filosofického zkreslování reality. V následující kapitole se z hlediska předchozích diskusí podíváme na to, jakou roli a pozici má v jejich filosofických systémech pojem rytmu.

\section{Whitehead a Dewey o rytmu}

Whitehead se rytmem poprvé systematicky zabýval v knize Zkoumání o principech př́rodního poznání (1919). V této knize se nesnažil formulovat metafyzický systém maximálního rozsahu, ale rozvíjel zde své pojetí filosofie přírody. Jeho cílem bylo vytvořit filosofický slovník, který by respektoval vědecká zjištění o neoddělitelnosti časové a prostorové dimenze, a narušoval tak tehdy často zastávanou představu přírody jako souboru stabilních objektů, které mohou jako takové teprve následně vstupovat do různých prostorových a časových vztahů. Klíčovým pojmem jeho filosofie přírody je pojem události (event), definovaný jako určitý extenzivní výsek průběhu přírody (passage of nature). ${ }^{23}$ Při své analýze však Whitehead sám sobě klade hranice: v této fázi svého filosofického vývoje nechtěl zkoumat procesy, jejichž prostřednictvím se př́roda ukazuje vnímateli, ale svou pozornost omezuje na procesy, které vnímatel může rozpoznat v rámci svého uchopení přírody. Příroda je zde uchopena jako vše, co je výstupem naší percepční aktivity či aktivity myšlení. ${ }^{24}$ Sebereflexivním obrácením pozornosti k této aktivitě samotné se Whitehead ve své filosofii př́rody nezabývá.

Př́roda je v této knize zkoumána na základě součinnosti dvou klíčových pojmů: události a objektu. Událost je chápána jako základní dílčí jednotka přírody, tak jak se ukazuje v naší percepci. Základním vztahem, do něhož různé události vstupují, je podle Whiteheada vztah extenze. Základními vztahy mezi událostmi by tedy bylo to, že bud' jedna událost zčásti nebo zcela obsahuje události jiné, nebo je sama zčásti nebo zcela součástí jiných událostí, nebo je od jiných událostí oddělena, nemá s nimi přímý kontakt. Jedním z Whiteheadových záměrů je ukázat, že „[č]as i prostor mají svůj zdroj v relaci extenze“, z čehož dále vyvozuje, „že čas i prostor vyjadřují vztahy mezi událostmi“.25 Pokud však Whitehead mluví o vztazích různých událostí, předpokládá, že je mezi sebou můžeme porovnávat. Jakékoliv porovnání je možné pouze u takových entit, které mají něco společného a v něčem se liší. Tímto společným a lišícím se jsou ve Whiteheadově filosofii prŕrody objekty, které „vyjadřují to, co v událostech rozpoznáváme jako stálé a v různých situacích jsou rozpoznány jako sebe-identické“. ${ }^{26}$ To, jaké objekty daná událost vykazuje, a způsob, jakým do ní vstupují, podle Whiteheada určuje, jakou povahu daná událost má. Právě v této souvislosti Whitehead zavádí pojem vstupu (ingression) objektu do události, který později používá i ve svých metafyzických

23 A. N. Whitehead, An Inquiry Concerning the Principles of Natural Knowledge, Cambridge University Press, Cambridge 1919, s. 14.

24 Tamtéž, vii.

25 Tamtéž, s. 61.

26 Tamtéž, s. 62-63. 
textech a který, jak jsme viděli, kritizoval Dewey. Whitehead zdůrazňuje, že v přírodě se nemůžeme setkat $s$ událostmi bez objektů nebo s objekty bez událostí: „Př́roda je taková, že v ní nemohou být žádné události ani žádné objekty bez toho, aby objekty vstupovaly do událostí. “27 Deweyho interpretace, že události mohou být ve Whiteheadově filosofii nahlíženy z hlediska preexistujícího řádu věčných objektů, je tímto výrokem přímo popírána. Př́roda jako výstup naší percepční aktivity podle Whiteheada vždy obsahuje fúzi změny a stability. Událost je neoddělitelná od kvalit, které exemplifikuje, a kvality se vždy vážou k určité události.

Whitehead dále popisuje, jak různé typy objektů vstupují do událostí, a snaží se ukázat, že smyslové objekty jako barvy, vůně nebo zvuky či percepční objekty jako židle, budova nebo strom jsou neméně reálné než vědecké objekty typu elektron, molekula či buňka. Všechny tyto typy objektů jsou skutečnými charakteristikami událostí a lze mezi nimi nalézt kontinuitu. Liší se však tím, jak do konkrétních událostí vstupují.

Pro nás je ovšem v tomto momentu důležité to, že i když se Whitehead ve své filosofii přírody soustředil na analýzu přírody ve smyslu výstupu percepční a myšlenkové aktivity, musel do svého systému přece jen zahrnout událost percepce a jí příslušné charakteristiky (percipující objekty), protože bez nich bychom o prrírodě v jím definovaném smyslu vůbec nemohli mluvit. Analýza percepčních objektů by ale již obsahovala sebereflexivní obrácení k samotnému procesu percepce a v tomto smyslu by překračovala cíle, které si ve své filosofii přírody vytyčil. Whitehead se ale přesto snaží alespoň naznačit povahu percepčních událostí a objektů a zajímavé je, že tak činí současně s definováním rytmu, jemuž je věnována drobná, šestistránková kapitola na konci Zkoumání.

Percipující objekt musí být podle Whiteheada objektem, který je schopen vykonávat spontánní a záměrnou aktivitu, je tedy objektem, který vykazuje život. A život je podle něj charakterizován právě rytmem. Rytmus Whitehead definuje jako „fúzi stejného a nového" a popisuje jej jako strukturované rozvíjení komplexního objektu, který charakterizuje vztahy dílčích objektů v rámci události. Whitehead jej nazývá útvar (pattern). Rytmus je fúzí stejného a nového v tom smyslu, že v něm můžeme rozpoznat určitou stabilní formu, tato forma však ještě není hotová, realizovaná, je teprve v procesu své realizace. Whitehead proto zdůrazňuje, že „pouhé opakování zabíjí rytmus stejně jistě jako pouhé setření rozdílư “28 Jestliže měl být rytmus pro Whiteheada prostředkem pro vymezení objektů vykazujících život, ukazuje se mu postupně, že pokud zmenšíme měřítko, budou se jako rytmické jevit i vztahy jednotlivých součástí molekul, které tvoří předmět, jenž se z naší perspektivy jeví jako pevný a stabilní. Rytmus se tedy jeví jako element, který proniká hluboko do neživé přírody. Živé organismy jsou podle Whiteheada výjimečné tím, že na základních rytmech tvoří stále komplexnější a propracovanější rytmy. Pevné objekty sice mohou na své nejnižší úrovni komplexity vyjadřovat rytmus, ten ale v komplexnějších patrech zaniká. U živých organismů je tomu naopak a vytvářejí vlastně rytmy rytmů. Zdá se však, že typ filosofického slovníku založeného na analýze vstupu objektů do událostí, jejichž základním vztahem je vztah extenze, nedokáže povahu rytmu adekvátně uchopit. Sám Whitehead si toho byl vědom a tvrdí:

27 A. N. Whitehead, The Concept of Nature, University of Michigan Press, Ann Arbor 1957, s. 144.

28 A. N. Whitehead, An Inquiry Concerning the Principles of Natural Knowledge, viz výše, s. 198. 
Rytmus je př́liš konkrétní na to, aby skutečně mohl být objektem. Nemůže být uvolněn z události tak, aby se stal opravdovým objektem, stal by se pouhým útvarem (pattern). Útvar činí to, že určité události vtiskuje svůj atomární (atomic) charakter. Celek události, který vykazuje tento atomární útvar, je jedinečným typem př́rodního prvku, není ani pouze událostí, ani pouze objektem, tak jak zde jsou definovány. ${ }^{29}$

V předchozím výkladu jsme viděli, že když Whitehead mluví o vstupu objektů do události, vždy hovoří o určité obsaženosti objektů v extenzivní události. V případě rytmu je tomu však jinak. Mluví zde o vtiskování určitého celistvého charakteru do události. Toto vtiskování ovšem není vstupem objektu do události ve smyslu obsaženosti objektu v události, protože rytmické schéma se v rámci události teprve rozvrhuje, nemá tedy sebe-identickou povahu jako objekt. Rytmus se proto Whiteheadovi jeví jako specifická procesuální entita, která překračuje rozvrh jeho filosofie přírody, nevejde se do jeho explanačního rámce. Jak jsem upozorňoval výše, základním typem vztahu, do něhož vstupují události, je v textech filosofie př́rody vztah extenze. Problematika rytmu však Whiteheada výrazně upozorňuje na myšlenku primární povahy procesu ve smyslu nastávání nového tvaru.

To, že pojmový systém vyvinutý pro jeho filosofii přírody nedokázal uspokojivě zahrnout problematiku rytmu, by ale znamenalo, že je příliš úzký, není schopen pojmout některé $\mathrm{z}$ relevantních faktů, a proto je ho třeba reformulovat. Tuto potřebu reflektuje sám Whitehead v poznámkách k druhému vydání Zkoumání z roku 1925, v nichž tvrdí: „pravdivou nauku, že základním (fundamental) pojmem je proces, jsem si tehdy s dostatečným důrazem neuvědomil. Extenze je odvozena od procesu a jej jím vyžadována. “30 Proces je zde chápán ve smyslu nastávání události, která ještě není plně př́itomná, ale směřuje ke svému zformování. Právě na motiv nastávání Whiteheada výrazně upozornila jeho analýza rytmu. Rytmus totiž není nereduktivně uchopitelný jako extenzivní jednotka (událost) analyzovatelná skrze sebe-identické charakteristiky (objekty). Podstatou rytmu je jeho nastávání. Nikdy před námi ve své konkrétnosti neleží celý. Takto pojatý rytmus je tedy procesem, který by měl podkládat i myšlenku extenze, dříve považovanou za klíčovou.

Whiteheadovy metafyzické texty, $\mathrm{v}$ nichž se zaměřuje na rozvinutí klíčové myšlenky procesu a snaží se o vytvoření pojmového schématu maximální explanační síly, můžeme proto chápat jako reformulaci a $\mathrm{v}$ jistém smyslu i zpřesnění pojmového schématu jeho filosofie prírody. ${ }^{31}$ Zajímavé je, že pojem rytmu se zde dostává do samotného centra jeho metafyzického systému. V rámci kategoriálního schématu své metafyziky totiž Whitehead rozlišuje kategorii „Ultimátního“, která je organizačním principem všech zbývajících

29 Tamtéž, s. 198-199. Útvar je zde Whiteheadem uchopen jako specifický typ komplexního věčného objektu, který vyjadřuje propojení objektů z různých částí události do jednotné struktury.

30 A. N. Whitehead, An Inquiry Concerning the Principles of Natural Knowledge, viz výse, s. 202. V roce 1925 Whitehead publikuje knihu Věda a moderní svět, v níž již rozpracovává typ filosofie založený na pojmu proces.

31 Tuto změnu v cíli i záměru jeho metafyziky samozřejmě doprovází změna v terminologii. Základní jednotkou skutečnosti již není událost (event), ale aktuální událost (actual occasion). Místo o objektech Whitehead mluví o věčných objektech, zavádí i množství dalších nových pojmů. Detailním změnám významu v terminologii se zde věnovat nemůžu. Pro všechny pojmy je však typické, že označují prvky, které se nějakým způsobem účastní procesu nastávání aktuální události. 
kategorií, a považuje za ni kreativitu jako proces vytváření nové skutečnosti na základě předchozí podoby reality. Ve chvíli, kdy se tento kreativní proces snaží charakterizovat, pomáhá si pojmem rytmu:

Kreativní proces je rytmický: přeskakuje (swings) z veřejnosti (publicity) mnoha věcí $\mathrm{k}$ individuální soukromnosti (privacy); a přeskakuje zpět od soukromého individua k veřejnosti objektivizovaného individua. První přeskok je ovládán účelovou prríčinou, která je ideálem, a druhý přeskok je ovládán působící příčinou, která je skutečností. ${ }^{32}$

Výše popsaný kreativní proces ve Whiteheadově metafyzickém systému charakterizuje dva souběžné typy pohybů, které vstupují do popisu základní jednotky jeho filosofického systému, aktuální události (actual occasion). Jedná se o pohyb konkrescence (concrescence), tedy nastávání, formování aktuální události do určitého útvaru, a pohyb přechodu (transition), kterým již ustavená aktuální událost podmiňuje podmínky nastávání událostí následujících. Pohyb konkrescence není „veřejný“ v tom smyslu, že se jedná o vlastní proces formování skutečnosti, daná událost ještě není v přísném slova smyslu faktem, nemá vyjádřitelnou extenzi, teprve nastává, je ve stadiu tvorby. Do extenzivního, veřejného kontinua vstupuje až po svém ustavení, pozměňuje ho a tím se stává součástí podmínek pro nastávání každé další nové aktuální události: „Aktuální události jsou stvoření (creatures), která nastávají a konstituují kontinuálně extenzivní svět. Jinými slovy, extenze nastává, ale ,nastávání samo extenzivní není. "33 Pro nás je zde důležité, že tento komplexní vývoj aktuální události má rytmický charakter a rytmický pohyb podle Whiteheada podkládá a konstituuje extenzi, která byla $\mathrm{v}$ jeho dřívějších textech považována za primární. Rytmus je v tomto pojetí chápán jako nastávání útvaru aktuální události, která po svém utvoření vstupuje jako reálný komponent do nastávání následující události, jako jeho působící příčina. Povahou rytmu je tedy nastávání útvaru nové události, aniž bychom ztratili kontakt s předchozím stavem skutečnosti.

Rytmus jako propojování působící a účelové př́íčinnosti je vyjádřen i v tom, jak Whitehead popisuje nastávání každé aktuální události. Ta má v jeho koncepci dva póly, fyzický a mentální. Fyzický pól je tvořen prehenzemi, což jsou v jeho koncepci dílčí procesy v rámci nastávání aktuální události, předchozího stavu skutečnosti, již konstituovaných událostí. V rámci mentálního pólu jsou prehenze fyzického nahlíženy v nových souvislostech, a to i v těch, které ještě nebyly realizovány. Právě skrze mentální pól, v jehož rámci jsou fyzické prehenze konfrontovány s různými kombinacemi věčných objektů, je do nastávání aktuální události zaváděna novost ve smyslu nové organizace prehenzí, vytvářejí se nové kontrasty mezi prvky dané aktuální události. Mentální pól zkušenosti je tedy zodpovědný za utváření různých typů záměrů a zhodnocování předchozí skutečnosti a směřování k proměně dosavadního stavu, „snaží se oživit masivní fyzický fakt, který je repetitivní, skrze novosti, které lákají“ ${ }^{34}$

Mentální pól však podle Whiteheada není nutně svázaný s vědomím, proniká veškerou zkušeností: „Žádná aktuální entita není zcela zbavena ani jednoho pólu, ačkoliv se

32 A. N. Whitehead, Process and Reality, viz výše, s. 151.

33 Tamtéž, s. 35.

34 A. N. Whitehead, The Function of Reason, Oxford University Press, London 1929, s. 26-27. 
může v různých aktuálních událostech lišit jejich význam. “" ${ }^{35}$ Mentální pól bude přítomen v události kamene, v události améby i v události člověka. Lišit se bude jen to, jak rozvinuté zapojení mentálního pólu dané události připouštějí, a jak výrazný kontrast tedy mohou vyvolávat ve srovnání s předchozím stavem skutečnosti. ${ }^{36}$ Určitý typ kontrastu s minulostí však bude podle Whiteheada prrítomen vždy, již jen díky časovému rozměru skutečnosti: „V nejdoslovnějším slova smyslu je plynutí času renovací světa idejemi. “37 Žádné dvě aktuální události tedy nebudou zcela stejné, protože každé nastávání v sobě zahrnuje jisté zhodnocení dosavadního stavu světa. Ten se ale nestále proměňuje, a umožňuje tedy možnosti, které dřívější stav nepřipouštěl. I existence neživých předmětů proto není pouhým opakováním stejného, vykazuje vývoj, a má tudíž rytmický charakter. Rytmický kreativní proces Whitehead na jiných místech popisuje i jako kontrast v rámci jednoty (contrast under identity). ${ }^{38} \mathrm{~K}$ tomuto pojmu se ještě vrátím ve třetí části textu, protože ve Whiteheadově systému úzce souvisí s problematikou estetické zkušenosti.

V této chvíli můžeme shrnout, že Whiteheadův přechod od filosofie prrírody k metafyzice zrcadlí jeho vlastní popis vývoje pojmových schémat filosofie jako racionálního dobrodružství, směřujícího k uchopení co nejobecnějších principů skutečnosti. Ve své filosofii prrírody se snažil zformulovat co nejpřesnější popis toho, co je výstupem naší percepce a myšlení. Ve chvíli, kdy usiloval uchopit jeden z okrajových motivů tohoto tématu, motiv rytmu, nahlédl, že jeho pojmové schéma nedokáže rytmus adekvátně pojednat. I na základě tohoto vhledu proto vyvinul nové, širší pojmové schéma, které již zohledňuje i vlastní proces uchopování přírody. V samém jádru jeho koncepce pak stojí právě pojem nastávání rytmu jako nastávání kontrastu s předchozím stavem skutečnosti při zachování jejich jednoty.

Také ve filosofii Johna Deweyho hraje rytmus zcela zásadní roli. Klíčovým pojmem Deweyho filosofie je pojem zkušenosti. Zkušenost je v jeho pojetí definována jako interakce organismu s jeho prostředím, není tedy pojata jako něco, co je vlastní pouze subjektu, není jeho subjektivní reakcí na daný objekt. Je jednotou situace, v níž se daná zkušenost uskutečňuje. Různé diference typu subjekt vs. objekt nebo mysl vs. hmota jsou podle Deweyho abstrakcemi z této původně jednotné zkušenosti. Výše zmíněné abstrakce mohou být užitečné pro zdůraznění některých rysů zkušenosti, ale filosofická úvaha by je neměla chápat jako základní a konkrétní východisko, protože by na jejich základě jen stěží mohla sestavit jejich původní propojenost a jednotu. Dewey se tedy stejně jako Whitehead vymezuje vůči klamu chybně umístěné konkrétnosti. Lékem je pro něj návrat k pojmu zkušenosti, který Dewey s odkazem na Williama Jamese označuje jako dvouobsažný (double-barrelled), což znamená, že označuje jak vlastní proces interakce určitého organismu s jeho prostředím, tak výsledek této interakce. ${ }^{39}$ Zkušenost jako interakce organismu s prostředím je tudíž především určitým procesem, který je ovšem struktu-

35 A. N. Whitehead, Process and Reality, viz výše, s. 239.

36 Pokud tedy Dewey mluví o tom, že Whiteheadovo pojetí věčných objektů může signalizovat statičnost jeho systému, vidíme zde, že Whiteheadovo pojetí je zcela opačné. Věčné objekty spouštějí novost.

37 A. N. Whitehead, Religion in the Making, Cambridge University Press, Cambridge, 1927, s. 100. Idejemi zde Whitehead nemíní věčné ideje Platónova typu, ale uvedení nových kontrastů skrze mentální pól aktuální události.

38 Srov. A. N. Whitehead, Religion in the Making, viz výše, s. 101, a A. N. Whitehead, Process and Reality, viz výše, s. 279-280.

39 J. Dewey, Experience and Nature, viz výše, s. 8. 
rován dosahováním dílčích cílů a další reformulací cílů nových. Ve chvilích, kdy se tento komplexní pohyb zkušenosti snaží popsat, si Dewey často pomáhá pojmem rytmu.

Dewey ve svých úvahách vychází především z lidské zkušenosti, snaží se však ukázat, že ta je ve výsledku strukturována na základě principu, který prostupuje celou živočišnou rriśíi. Tímto základním principem je překonávání „rytmických krizí, které frázují (punctuate) tok života“" ${ }^{0}$ Základní strukturace života má tedy podle Deweyho rytmickou povahu, která je vyvolávána potřebou řešení problematické situace, do níž organismus vstupuje. Rytmus zkušenosti je vlastně vyvolán neustále napjatým vztahem mezi organismem a jeho prostředím. Jakýkoliv organismus se bude neustále dostávat do konfliktu s okolní skutečností, a aby se udržel naživu, je nutné, aby znovu a znovu nastoloval vyvážený stav se svým okolím. Rytmický proces strukturující pohyb deweyovské zkušenosti je tedy procesem harmonizace organismu s jeho prostředím. Je pohybem od nerovnováhy a nestability $\mathrm{k}$ novému typu řádu. Tento harmonizační proces je podle jeho názoru nezbytný pro udržení života. Pokud se určitý typ harmonizace se svým prostředí nepodaří nastolit, organismus bude směřovat ke smrti. Na druhou stranu je vývoj, růst organismu umožněn pouze skrze toto vyrovnávání se s problematickou situací, usmiřování disharmonií: „Živý organismus roste (grows), pokud je dočasná roztržka [s prostředím - pozn. M. K.] přechodem k širší rovnováze energií organismu s podmínkami, za nichž žije." ${ }_{11}$

Je zajímavé, že užv tomto okamžiku si můžeme povšimnout silné analogie s Whiteheadovým uchopením rytmu. Oba rytmus nejprve nahližejí ve spojitosti s živými organismy, ani jeden z nich nepojímá rytmus jako prosté opakování již ustaveného tvaru. U obou je rytmus také nerozlučně spjat s procesem kreativity, je způsobem, jak vytvořit nový typ uspořádání skutečnosti. I když Dewey cíleně vychází z rytmu, jak se ukazuje v lidské zkušenosti, ve svých textech dospívá k tomu, stejně jako Whitehead, že je dominujícím principem i v neživé prírodě. Rytmus je totiž i pro Deweyho především specifickým propojením změny a řádu, stejného a nového, a díky tomu proniká veškerou skutečností.

Existence mnohých ilustrací rytmu v přírodě je dobře známým faktem. Často je zmiňován příliv a odliv, cykly změn měsíce, pulzy toku krve, anabolismus a katabolismus všech živých procesů. To, že jakákoliv jednota a pravidelnost přírodních změn je rytmem, již tak všeobecně přijímáno není. Termíny „přírodní zákon“ a „přírodní rytmus“ jsou synonymní. Jakmile je pro nás příroda více než neustále proměnlivý tok, který postrádá řád, více než vír zmatků, pak je charakterizována rytmem. [...] [R]ytmus je univerzálním schématem existence, které podkládá veškeré uskutečňování řádu v rámci změny $[\ldots] .{ }^{42}$

Dewey tedy, stejně jako Whitehead ve svých metafyzických textech, pokládá rytmus za základní organizující princip reality. Má-li příroda mít nějaký rád, má-li se nám ukazovat jako určitý typ místa, ve kterém žijeme, bude vždy vykazovat rytmický charakter. Whiteheadova výtka, že Deweyho filosofický systém je př́liš opatrný tedy - přinejmenším v tomto kontextu - není zcela na místě. Dewey dokonce stejně jako Whitehead rozli-

40 J. Dewey, Art as Experience, Putnam' Sons, New York 1980, s. 7.

41 Tamtéž, s. 14.

42 Tamtéž, s. 149-150. Později Dewey dochází k obecné definici rytmu jako „uspořádané variace změn“ (ordered variation of changes). Toto Deweyho vymezení je v zajímavé shodě s Whiteheadovým pojetím rytmu jako kontrastu v rámci identity. Srov. tamtéž, s. 154. 
šuje rytmy různé komplexity podle toho, zda dokážou na základních rytmech stavět další rytmická uspořádání: „S větší komplexitou organismu je obměňován a prodlužován jeho rytmus zápasu a souladu s prostředím. Začíná v sobě obsahovat nekonečnou mnohost subrytmů. “43 Dewey dále ukazuje, že překročení hranice rytmu jako uspořádané změny způsobuje „destrukci a smrt, z nichž jsou však budovány další rytmy“44 Tato myšlenka opět plně souzní s Whiteheadovým pojetím rytmu jako základního pohybu aktuálních událostí.

Příklad Deweyho filosofické opatrnosti, o níž se zmiňuje Whitehead, bychom však mohli najít v určité inkonzistenci, s níž se problematice rytmu věnuje. Ačkoliv Dewey ve výše citované pasáži tvrdí, že rytmus je univerzálním schématem existence, na jiném místě od této definice poněkud ustupuje kvůli tomu, že z hlediska lidské zkušenosti se některé objekty zdají být bez rytmu. Uvádí proto, že „plyn rovnoměrně pronikající uzavřenou nádobu, přívalová povodeň překračující všechny překážky, nehybný rybník, nepřerušená pustina pouště a monotónní dunění jsou celky bez rytmu“. 45 Tato úvaha se velice podobá Whiteheadovým raným popisům rytmu z jeho spisů věnovaných filosofii př́rody, v nichž uvádí prríklad mlhy a krystalu jako objektů postrádajících rytmus. Mlha je příliš málo uspořádaná a krystal naopak vyjadřuje přemíru uspořádanosti. Zajímavé je, že Dewey ve větě, která prrímo následuje po uvedených příkladech, tvrdí že rybník rozpohybovaný vlnami je již př́ikladem jednoduchých přírodních rytmů. Ve svých metafyzických textech již Whitehead vychází z pojetí rytmu jako organizujícího principu reality, a poukazoval by tedy také na níže položené rytmické procesy, které vykazuje i povodeň, jezero, pouštní pustina, mlha nebo krystal. Skrze jeho metafyzický pojmový systém je proto možné ukázat, že rytmické procesy probíhají i ve zdánlivě „strnulém rybníku“, a exemplifikovat to, jak tyto skryté rytmy vedou ke komplexnějším rytmům, jež umožňují objevení se vln na jeho hladině. Whiteheadovy metafyzické texty by tudíž rytmickou povahu skutečnosti respektovaly důsledněji. A to i díky analýzám vstupu věčných objektů do nastávání aktuální události.

Deweyho i Whiteheadovy úvahy o rytmu tedy vykazují pozoruhodné shody. Pokud bychom však na obě koncepce pohlédli detailněji, viděli bychom, že Deweyho formulace se k rytmu stavějí z hlediska toho, co můžeme v přírodě i naší zkušenosti vypozorovat. Snaží se především popsat jeho různé podoby, tak jak se ukazují vnímajícímu jedinci. Whiteheadovy úvahy přece jen vedou dále. Snaží se popsat vlastní proces nastávání rytmu jako souběhu působící a účelové př́ičiny. Podobný pokus o popis vlastního procesu nastávání rytmického vzorce u Deweyho nenajdeme. Viděli jsme, že oba autoři při popisu rytmu vycházejí z toho, jak se rytmus projevuje u živých organismů. Oba také jeho působnost protahují až k neživým organismům. Dewey však analýzu rytmu vposled vztahuje pouze k jevům či zkušenostem, které se jeví v pohybu, Whitehead tímto způsobem působnost rytmu neomezuje a snaží se ukázat, že v i pozadí fenoménů jevících se jako statické probíhají rytmické procesy, které sice nemůžeme přímo vnímat (jsou příliš rozptýlené, pomalé či naopak rychlé), ale můžeme je doložit intelektuální analýzou vnímatelné zkušenosti. V tomto smyslu tedy nachází kontinuitu tam, kde Dewey poukazuje pouze na rozdíl.

43 Tamtéž, s. 23.

44 Tamtéž, s. 16.

45 Tamtéž, s. 155. 
Nejobecnější, nejpodrobnější a nejpropracovanější popisy různých druhů rytmů Dewey překvapivě nepodává v knize Zkušenost a př́roda, ve které plně formuluje svůj filosofický systém založený na širokém pojetí zkušenosti, ale v knize Umění jako zkušenost, v níž se snaží popsat souvislosti a rozdíly každodenního života a umění a prokázat tezi, že estetická zkušenost proniká hluboko do praktického života. Umění a estetická zkušenost se proto může jevit jako klíč pro obecnější uchopení rytmu. Tento motiv však najdeme i u Whiteheada, i on v místech, kde rozvádí obecné charakteristiky rytmu, často poukazuje na jejich souvislost s uměním a estetickou zkušeností. Poslední oddíl tohoto textu proto bude věnován právě tomu, jak souvislost rytmu a estetické zkušenosti oba autoři tematizují.

\section{Rytmus a estetická zkušenost}

John Dewey se v knize Umění jako zkušenost především snaží překlenout rozpor, s nímž se můžeme setkat v úvahách o uměleckých dílech. Umělecká díla jsou na jedné straně oceňována jako významná součást jakékoliv společnosti a fungující kultury, na straně druhé jsou často pojímána jako umělecké produkty definované opozicí vůči naší běžné zkušenosti. Dewey se snaží ukázat, že význam uměleckých děl nebude nikdy pochopen, pokud neukážeme, jak se tyto umělecké produkty vztahují k naší každodenní zkušenosti a jak ji ovlivňují. Proto se snaží analyzovat lidskou zkušenost jako takovou a ukázat, že již v její základní povaze najdeme zárodky estetického zakoušení. Právě v této souvislosti zmiňuje rytmický a kreativní rozměr každé zkušenosti, která nebyla vyprázdněna pouhým opakováním již dříve naučeného vzorce jednání či rezignací na aktivní vztah k reálnému světu.

Ve chvíli, kdy přemýšlí o podobě světa, která by nepřipouštěla estetickou zkušenost, mluví o dvou variantách. Estetická zkušenost by podle jeho názoru neměla místo ve světě pouhého toku nerozčleněného dílčími sjednoceními zkušenosti a ve světě, který by byl již hotový, završený a nepodněcoval by k novému sjednocování zkušenosti. Vzpomeneme-li si na Whiteheadovu poznámku o tom, že rytmus je zabíjen jak pouhým opakováním, tak setřením jakéhokoliv rozdílu mezi prvky zkušenosti, mohli bychom říci, že Deweyho svět nepřipouštějící estetickou zkušenost by byl svět bez rytmu. Deweymu se zde tedy objevuje myšlenka úzkého propojení estetické zkušenosti a rytmu.

V předchozí části jsme viděli, že náš svět je podle Deweyho na propojování a koexistenci různých typů rytmu založen. Pokud by tedy Dewey rozvedl svou úvahu až k nejvyššímu patru obecnosti, mohl by začít sledovat myšlenkovou linii, jež by mohla vést k estetické povaze dějícího se světa jako takového. Rozvedení této myšlenky budeme moci později sledovat u Whiteheada, Dewey ji však netematizuje, jeho pozornost je soustředěna na analýzu lidské zkušenosti a jejích shod a rozdílů se zkušeností dalších živých organismů. Tvrdí, že „,[kvůli] tomu, že svět, ve kterém žijeme, je kombinací pohybu a uzavření, trhlin a nových sjednocení, může živé stvoření zakoušet estetickou kvalitu. [...] Moment přechodu od narušení $\mathrm{k}$ harmonii je momentem nejintenzivnějšího života. " 46 $\mathrm{K}$ tomu, abychom realizovali estetickou kvalitu potenciálně prŕítomnou v rámci usku-

46 Tamtéž, s. 17. 
tečňující se problematické situace, je třeba, abychom do jejího řešení vstoupili zevnitř, využili potenciality, které nabízí, a v rámci jejich rozvíjení postupně překračovali omezení, jež nám na začátku vtiskovala. Tímto zpơsobem pak dospějeme k novému dosažení rovnováhy se svým prostředím, nové harmonizaci zkušenosti. Pouhé mechanické opakování řešení, která jsme již vyzkoušeli dříve, či odstoupení od řešení dané situace rytmický vzorec ochuzuje, zkušenost se stává povrchní a estetická kvalita je oslabena.

Zkušenost, která bude rozvíjet estetickou kvalitu situace, podle Deweyho specifickým způsobem sjednocuje minulost, př́itomnost a budoucnost: „Člověk je plně sjednocen, a tedy plně naživu, pouze tehdy, když ho netrápí minulost a nezneklidňuje budoucnost. Umění se zvláštní intenzitou oslavuje ty momenty, v nichž minulost posiluje přítomnost a budoucnost urychluje to, co je právě ted.' " ${ }^{77}$ Podstatou estetické percepce je tedy podle Deweyho rytmické přetvoření minulé zkušenosti do nového vzorce, který má relevanci i pro bezprostřední budoucnost. Poznamenává, že člověk vnímající esteticky se nemůže nehodících se momentů minulosti jednoduše zbavit ani u minulé zkušenosti beze změny setrvávat. V tomto smyslu estetická kvalita podle Deweyho proniká jak do dominantně praktické, tak do dominantně teoretické zkušenosti. Zdůrazňuje, že „žádná zkušenost jakéhokoliv druhu nenabude jednoty, pokud nebude mít estetickou kvalitu“" ${ }^{8}$ Tato estetická kvalita však nebude mít povahu vlastnosti, která je ke zkušenosti jednoduše přidána. Bude se rozvíjet až uvnitř vlastního procesu zkušenosti skrze rytmické překonávání rozporů ústících do dočasného nalezení harmonie organismu s jeho prostředím. Estetická kvalita bude $\mathrm{v}$ tomto dění určovat směr pohybu zkušenosti, přičemž konkrétní způsob naplnění cíle (at' už praktického nebo teoretického) nebude do této zkušenosti vložen zvenčí, ale bude se vytvářet až v rámci rytmického pohybu zkušenosti. Estetická kvalita tedy bude mít rytmickou povahu. Právě umění podle má podle Deweyho schopnost rozvíjet zkušenosti, v nichž se estetická kvalita rozvine v plné intenzitě.

Pokud však Dewey již dřive tvrdil, že rytmus je univerzálním schématem existence, měl by připustit, že určitá podoba chudšího rytmu vstupuje i do zmechanizované zkušenosti, která se nehodících se momentů zkušenosti zbavuje, dále je nerozvíjí a estetickou kvalitu podle Deweyho postrádá. Dewey se však tématem „chudších rytmů“ př́liš nezabývá, protože pro něj bylo důležitější ukázat souvislost mezi kreativní mimouměleckou zkušeností, která je podle něj nezbytná pro udržení života, a zkušeností s uměním.

Dewey v rámci svých úvah o umění na základě výše představených tezí ukazuje, že je třeba důsledně rozlišovat mezi uměleckým produktem (art product) a vlastním uměleckým dílem (work of art). Umělecký produkt není vlastním uměleckým dílem, ale hmotným objektem, který má potenciál k tomu, aby skrze něj mohl recipient rozvinout svůj kontakt s uměleckým dílem. Umělecké dílo se podle Deweyho ukazuje až na základě komunikace s recipientem, je konstituováno na základě jeho zkušenosti. Umělecké dílo jako zkušenost má podle Deweyho rytmickou povahu propojování a harmonizace různých kontrastů, které obsahuje umělecký produkt. Dewey věnuje značnou část svého výkladu, aby ukázal, že rytmus není doménou jen tzv. časových umění, ale i těch, která jsou označována jako prostorová nebo plošná. Týká se totiž toho, jak je umělecké dílo realizováno ve zkušenosti, tedy toho, jakým způsobem existuje:

47 Tamtéž, s. 18.

48 Tamtéž, s. 40. 
Tyto rytmy, i když jsou vtěleny ve vnějším objektu, který je sám o sobě uměleckým produktem, jsou estetickými až tehdy, pokud se stávají rytmem v rámci vlastní zkušenosti. Tento rytmus toho, co je zakoušeno, je něčím zcela odlišným od intelektuálního rozpoznání, že vnější věc má rytmus. Stejně odlišným jako percepční zážitek tlumených harmonických barev od matematických rovnic, jimiž je definuje vědec. ${ }^{49}$

Dewey se tedy jednak snaží ukázat, že umělecké dílo existuje pouze jako rytmický pohyb, který se rozehrává ve zkušenosti, jednak upozorňuje na to, že tímto zpo̊sobem umění intenzifikuje a zaměřuje pozornost na procesy, které probíhají v každé úspěšné interakci organismu s prostředím. Čím je však tato intenzifikace umožněna? „Kromě lhostejnosti a odporu př́rody vưči lidským zájmům tu musí být určitá soudržnost prrírody a člověka, jinak by nemohl existovat. V umění jsou uvolněny ty vzájemně slučitelné síly, které nepodporují ten nebo onen zvláštní cíl, ale vlastní procesy prožívané zkušenosti. “50 Umělecké dílo tedy podle Deweyho postrádá vnější cíl, který je typický pro zkušenost dominantně praktickou nebo teoretickou, a díky tomu uvolňuje pozornost, aby se mohla soustředit na vlastní prožití rytmických změn. Díky tomu dokáže upozornit na vnitřní organizaci praktických či teoretických zkušeností, které, mají-li být úspěšné a sjednocené, obsahují rytmicky se rozvíjející estetickou kvalitu.

Tímto způsobem se Dewey snaží poukázat na hluboký vztah mezi uměním a mimouměleckou zkušeností, který již v jeho době přestává být zřetelný a je zakryt nedůvěrou vůči pojmu zkušenost na jedné straně a konvenčními reakcemi na umění na straně druhé. $\mathrm{V}$ tomto diagnostickém podniku Dewey rozhodně uspěl a jeho analýzy různých umění dodnes působí svou pronikavostí. V rámci svých zkoumání však dochází i k obecným metafyzickým tvrzením o povaze skutečnosti. Tyto poznámky ovšem nejsou plně rozvinuty a do značné míry tak ustupují jeho sociálně kritickým zájmům. Jedná se především o pokus o systematické nahlédnutí skutečnosti z hlediska rytmu a estetické zkušenosti. Tento výklad skutečnosti Dewey na některých místech provádí, nikdy ho však nedovádí do systematické podoby. Systematické a důsledné rozvinutí tohoto filosofické prrístupu ale můžeme nalézt u Alfreda Northe Whiteheada.

Rovněž Whitehead propojuje své úvahy o rytmu s problematikou estetické zkušenosti. V předchozí části jsme viděli, že problematika různě komplexních rytmů tvoří jádro Whiteheadova metafyzického systému, protože podkládá jeho úvahu o způsobu nastávání aktuálních událostí. Upozorňoval jsem i na to, že rytmický proces je popisován skrze pojem kontrastu v rámci jednoty. Tento pojem vyjadřuje podmínky nastávání jakékoliv nové aktuální události. Ta musí být uspořádána takovým způsobem, aby se svým základem (ground), tedy světem, z něhož vychází, udržela určitý typ jednoty, a současně musí vưči svému základu vykazovat kontrast. Musí být od něj rozlišitelná jako samostatná jednotka. Tento princip v podstatě podkládá nastávání jakékoliv nové aktuální události a za vytváření nových kontrastů je odpovědný zejména mentální pól aktuální události, tedy různé způsoby propojení fyzických prehenzí s věčnými objekty. V souvislosti s výše zmíněnou definicí kontrastu v rámci jednoty, která vyjadřuje rytmický pohyb nastávání aktuálních událostí, Whitehead tvrdí, že „[t]yto dva principy jsou odvozeny z nauky, že

49 Tamtéž, s. 162.

50 Tamtéž, s. 185. 
aktuální fakt je faktem estetické zkušenosti. Jakákoliv estetická zkušenost je pocitováním, které vzniká skrze uskutečňování kontrastu v rámci jednoty“ 51

Aktuálním faktem je však ve Whiteheadově systému jakákoliv skutečnost procházející fází nastávání: nic takového jako aktuální událost, která nikdy nenastávala, není ve Whiteheadově systému možné. Pokud tedy tvrdí, že „aktuální fakt je faktem estetické zkušenosti“, jedná se o velmi silné tvrzení, protože znamená, že každý proces nastávání našeho světa má estetickou povahu. $V$ této formulaci se jedná o značné rozšíření pojmu estetické zkušenosti oproti tomu, jak je v estetice běžně používán. Můžeme se tedy ptát, co Whiteheada k tomuto širokému užití pojmu estetická zkušenost vede a jak je tento pojem v jeho filosofii dále rozpracován.

Již v první části tohoto textu jsem upozorňoval na Whiteheadovu filosofickou metodu deskriptivní generalizace. Podle této metody každý filosofický systém vychází z popisu určité omezené oblasti zkušenosti a tyto deskripce jsou poté imaginativně rozvíjeny do co nejobecnějšího systému kategorií. Pojmové schéma každého filosofického systému pak bude vykazovat jisté zabarvení svou výchozí oblastí. Ve Whiteheadově vlastní filosofii je touto výchozí oblastí, jak sám dosvědčuje, oblast estetiky. ${ }^{52}$

V této souvislosti Whitehead poznamenává, že estetická zkušenost „odkrývá samotný význam věci“' ${ }^{53} \mathrm{Na}$ co tedy estetická zkušenost podle Whiteheada tak intenzivně poukazuje, jakou charakteristiku reality odkrývá? Whitehead vyzdvihuje, že estetická zkušenost má dvě úzce propojené strany. Jednak je silně individuálně a emocionálně zabarvená, poukazuje na vlastní proces percepce daného recipienta, současně však neméně silně odkazuje $\mathrm{k}$ danému objektu jako svému zdroji. $\mathrm{V}$ tomto náhledu tedy můžeme vidět určitý předobraz propojení účelové a působící příčiny, jež vstupuje do samotného popisu aktuální události. Whitehead ovšem zdůrazňuje, že estetická zkušenost rovněž intenzivně směřuje ke svému završení a ukazuje selektivní povahu svého vlastního procesu. Whitehead v tomto ohledu tvrdí:

Zvažme dobrý obraz. Vyjadřuje jednotu vzájemné relevance a odporuje návrhu jakéhokoliv doplnění. Nemůže do něj být umístěno ani trochu šarlatové barvy navíc, aniž by byla zničena jeho jednota. Důležité je, že jak subjektivní jednota pocitování, tak objektivní jednota vzájemné relevance vyjadřují vztah vylučování vzhledem ke světu ležícímu za nimi. Máme tu dovršení, které vylučuje alternativy. ${ }^{54}$

Estetická zkušenost tedy odkazuje na několik důležitých momentů, které se objevují i ve Whiteheadově popisu nastávání aktuální události. Odhaluje neoddělitelnost subjektivního a objektivního pólu dané zkušenosti, vykazuje charakter rytmického směřování ke svému završení ve smyslu harmonizace různých dat do jednotného celku, a upozorňuje na to, že svět nikdy nemůžeme uchopit v jeho úplnosti. Estetická zkušenost ve svém harmonizačním procesu vždy obsahuje selekci, vyloučení některých aspektů skutečnosti. Každý estetický prožitek je pro Whiteheada nahlédnutím skutečnosti ze své vlastní perspektivy. Právě tyto motivy Whitehead rozpracoval ve

51 A. N. Whitehead, Religion in the Making, viz výše, s. 101-102.

52 Srov. A. N. Whitehead, Remarks, viz výše, s. 185.

53 Tamtéž.

54 Tamtéž. 
svých popisech nastávání aktuální události a dalších celků reality, které jsou na jejím základě vystavěny. Celý jeho systém je tedy zabarven rysy takto pojaté estetické zkušenosti a tento samotný pojem v jeho pojetí získává značně širokou definici, zahrnující jak živé, tak neživé entity.

Takto široká definice estetického prožitku je patrná i ve Whiteheadově pojetí krásy. $\mathrm{V}$ této souvislosti dokonce tvrdí, že „[t]eleologie Univerza směřuje k vytváření krásy. Existence jakéhokoliv systému skutečností, který je v jakkoliv širokém smyslu krásný, je proto oprávněná. Může však selhat v jiném smyslu, tím, že potlačuje více Krásy, než vytváríi “ ${ }^{55} \mathrm{Na}$ tomto místě je třeba upozornit na několik specifik Whiteheadova pojetí krásy. Krása pro Whiteheada ve svém základním významu není vlastností předmětu, ale „vzájemným přizpůsobením různých složek v rámci události zkušenosti“ ${ }^{56}$ Krása má tedy u Whiteheada, stejně jako estetická zkušenost u Deweyho, zkušenostní povahu. Stejně jako Dewey rozlišuje mezi aktuálně přítomným zakoušeným uměleckým dílem a uměleckým produktem jako hmotnou fixací tohoto objektu, rozlišuje Whitehead na obecnější rovině mezi dvěma významy pojmu krása. Primárním významem je právě zmíněné přizpůsobení, tedy harmonizace různých složek v rámci zkušenosti, druhým a odvozeným je připsání krásy určitému objektivnímu obsahu. Whitehead př́mo tvrdí, že „[o]bjektivní obsah je krásný na základě Krásy, která by byla danou událostí př́íhodným výkonem její spontaneity realizována“" 57

Cílem realizace krásy v rámci aktuální události je podle Whiteheada usmíření jejích disharmonických složek. U Deweyho jsme viděli, že zkušenost s estetickou kvalitou vzniká na základě překonávání rozporů mezi organismem a jeho prostředím. Tento motiv je, opět na obecnější úrovni, přítomný i u Whiteheada. Aktuální svět jakékoliv události totiž bude obsahovat disharmonické elementy. Tato disharmonie podle Whiteheada pramení z faktu, že „mody krásy jsou rozmanité a ne vždy kompatibilní “ 58 Intenzita zkušenosti krásy proto vychází právě z překonávání rozporů, harmonizace disharmonických složek aktuální události. Toto usmiřování disharmonií však může probíhat různými způsoby, a Whitehead proto rozlišuje mezi různými úrovněmi či mody krásy. Každé dílčí dosažení kontrastu v rámci identity má rytmický charakter a Whitehead ho bude považovat za zkušenost krásy, lišit se však bude její komplexita a intenzita. Ta je podmíněna tím, aby bylo v rámci nastávání dané aktuální události dosaženo co nejširších a nejkomplexnějších kontrastů mezi různými složkami.

Whiteheadovo použití pojmu krásy je tedy velice široké a týká se opět jak událostí neživé př́rody, tak událostí, které jsou součástí živých organismů. V jeho úvahách proto můžeme vidět i rozvedení myšlenky, kterou naznačil, ale nevyužil Dewey, o estetické povaze dějícího se světa jako takového. Estetický prožitek či prožitek krásy se ve Whiteheadově systému stává ontologickým principem.

Ve Whiteheadově filosofii by krásu vykazovaly dokonce i „chudší rytmy“ Deweym odsuzované mechanické zkušenosti, která nehodící se prvky zkušenosti jednoduše opomíjí. Jednalo by se však o velice nízký stupeň krásy, který Whitehead popisuje jako znecitlivění (anaesthesia) a který je založen právě na vyloučení disharmonických prvků z procesu

\footnotetext{
A. N. Whitehead, Adventures of Ideas, viz výše, s. 265.

Tamtéž, s. 252.

57 Tamtéž, s. 255.

8 Tamtéž, s. 266.
} 
nastávání události. Tento typ harmonizace by však selhával ve smyslu výše uvedeného citátu. Potlačoval by více krásy, než by vytvářel. Selhával by, protože by nerozvíjel potenciální bohatství kontrastů, a ztrácel by tak i na své intenzitě.

Zatímco Dewey by se - v rozporu se svou obecnou definicí rytmu - zdráhal označit tyto „chudé rytmy“ vůbec za rytmy a upíral by jim jakoukoliv estetickou kvalitu, Whiteheadův konceptuální systém umožňuje tento rozpor vyřešit a současně ukázat, proč Dewey oprávněně zaměřuje svou pozornost na komplexnější způsoby harmonizace. I na této úrovni nám tedy Whiteheadova spekulativní filosofie umožňuje hlouběji podložit diference, které ve svých textech ukazuje Dewey. Na druhou stranu je však třeba říci, že Whitehead při pokusu o proniknutí k metafyzickým základům skutečnosti často výrazně modifikuje běžný význam pojmů, které používá, a mnohdy jej velice výrazně rozšiřuje. Tím však jeho filosofické pojmy do jisté míry ztrácejí zřejmou souvislost s naším aktuálním živým světem. Whitehead například mluví o zkušenosti elektronu, kráse zakoušené neživými předměty, estetické zkušenosti molekuly. Pokud tedy chceme skrze jeho filosofii formulovat rozdíl mezi estetickou a praktickou zkušeností, tak jak ji zakouší člověk, musíme estetickou zkušenost člověka rekonstruovat na základě typů syntéz, které jsou lidským bytostem dostupné. Deweyho filosofický slovník (přestože i on vykazuje rozdíly vůči slovníkovému významu slov) souvislost s běžným používáním slov nikdy neztrácí, a proto dokáže snáze popsat diference, které jsou v našem aktuálním životě významné.

\section{Závěr}

V této studii jsem se pokusil ukázat, jak John Dewey a Alfred North Whitehead vzájemně reflektovali své filosofické systémy. Oba filosofii toho druhého silně oceňovali, každý v ní však nalézá problematické ohnisko. Whitehead vytýká Deweymu př́lišnou opatrnost a nedostatek systematického uchopení skutečnosti. Dewey naopak shledává ve Whiteheadově filosofii stopu statičnosti, kterou má reprezentovat jeho pojetí věčných objektů a jejich „vstupu“ do aktuálních událostí. Na základě představení myšlenek o rytmu a estetické zkušenosti u obou autorů jsem se pokusil ukázat, že takto vyhrocená kritika by byla vůči oběma systémům příliš přísná. Dewey sice svou filosofii zakládá na analýze lidské zkušenosti, na jejím podkladě však často dochází k zajímavým a objevným zobecněním, která se v řadě ohledů blíží výsledkům Whiteheadových analýz. Deweyho popisy tedy dalece př̀kračují bezpečnou zónu popisu dobře známých faktů a vykazují charakter dobrodružství, který je podle Whiteheada podstatou filosofických zkoumání. I proto jeho úvahy dodnes lákají k dalšímu rozvinutí. Zároveň bylo ukázáno, že Dewey své úvahy nerozpracovává do jednotného metafyzického systému, a proto mohou být úspěšně doplněny a podpořeny Whiteheadovým kategoriálním systémem. Deweyho obava, že zapojení věčných objektů do Whiteheadova systému vnáší prvek statičnosti, je dle mého názoru rovněž neoprávněná. Pokusil jsem se ukázat, že Whiteheadovo pojetí věčných objektů nemá povahu předem definovaného vzorce, kterému se nastávání aktuálních událostí musí přizpůsobit, ale naopak podmiňuje fungování tzv. mentálního pólu aktuální události, který do ní zavádí možnost nového uchopení skutečnosti, konstrukci nových kontrastů, a tedy prvek nového. Směřování k novému (aniž bychom ztratili kontakt s již dosaženým) je ostatně princip, na němž je jak Whiteheadova, tak Deweyho filosofie založena. 


\section{Poděkování}

Text vznikl za podpory grantového projektu GA16-13208S Proces a estetika: explicitní a implikovaná estetika v procesuální filozofii Alfreda North Whiteheada.

\section{LITERATURA}

Bergson, H., Art as Experience, Putnam' Sons, New York 1980.

---, Experience and Nature, George Allen \& Unwin, London 1929.

---, Myšlení a pohyb, Mladá fronta, Praha 2003.

---, Whitehead's Philosophy, The Philosophical Review, roč. 46, 1937, č. 2, s. 170-177.

James, W., Pragmatismus. Nové jméno pro staré zpưsoby myšlení, Centrum pro studium demokracie a kultury, Brno 2003.

Whitehead, A. N., Adventures of Ideas, Free Press, New York 1967.

---, Analysis of Meaning, in: Whitehead, A. N., Essays in Science and Philosophy, Rider and Company, London, 1948, s. 83-99.

---, An Inquiry Concerning the Principles of Natural Knowledge, Cambridge University Press, Cambridge 1919.

---, Dialogues, Little, Brown and Company, Boston 1954.

---, John Dewey and His Influence, in: Schilpp, P. A. (ed.), The Philosophy of John Dewey, Northwestern University, Evanston \& Chicago 1939, s. 475-478.

---, Process and Reality: An Essay in Cosmology, Corrected Edition, The Free Press, New York 1978.

---, Religion in the Making, Cambridge University Press, Cambridge 1927.

---, Remarks, The Philosophical Review, roč. 46, 1937, č. 2, s. 178-186.

---, Science and the Modern World, Macmillan, New York, 1964.

---, The Concept of Nature, University of Michigan Press, Ann Arbor 1957.

---, The Function of Reason, Oxford University Press, London, 1929. 